\title{
Fans identification: the bright side of football sponsorship effectiveness
}

\section{Alfredo Silva}

To cite this article: Alfredo Silva (2020) Fans identification: the bright side of football sponsorship effectiveness, Journal of Sport \& Tourism, 24:4, 251-267, DOI: 10.1080/14775085.2020.1824800

To link to this article: https://doi.org/10.1080/14775085.2020.1824800

册Published online: 04 Oct 2020.

Submit your article to this journal 준

LII Article views: 300

Q View related articles $₫$

View Crossmark data \lceil

Citing articles: 1 View citing articles $\square$ 


\title{
Fans identification: the bright side of football sponsorship effectiveness
}

\author{
Alfredo Silva ${ }^{a, b}$ \\ ${ }^{a}$ Sport Science School of Rio Maior, Department of Sport Management - Polytechnic Institute of Santarém, \\ Rio Maior, Portugal; 'bife Quality Research Center (CIEQV), Santarém, Portugal
}

\begin{abstract}
Football events are by far one of the most preferred leisure activities amongst fans around the world, namely when it involves their favorite team. The measurement of sponsorship results is seen as a research priority, however, some results found are not consistent, in which mediation is seen as a research priority. This research intends to: (i) determine fan identification effect on perceived congruency between sponsor and sponsored team, and on intentions towards buying sponsor's products, and; (ii) determine the mediation role of perceived congruence. In total, 1399 fans from a top three Portuguese professional football team were considered for analysis. For statistical analysis, Structural Equation Modeling was used. Results show that higher levels of fans' team identification lead to higher intention to buy sponsor's products, and the most innovative result was the relevant mediating role of the perceived congruence in the formation of the purchase intention on sponsor's products.
\end{abstract}

\section{ARTICLE HISTORY}

Received 26 June 2020

Accepted 14 September 2020

\section{KEYWORDS}

Congruence; purchase intention; fan identification; football fans; sponsorship

\section{Introduction}

Attending football events is by far one of the most preferred leisure activities amongst fans around the world, namely when it involves their favorite team. Amongts the Professional football leagues of Europe, Germany remains the leading country with an admirable average of 43,449 spectators per game at the time 2018-2019 (Worldfootball, 2019).

Football teams are the main engine for fans' interest in viewing sport. There is no doubt that this sport is of public interest, it has a high level of visibility, gives spectators an emotional connection, and can generate a state of excitement and affective bonding with the public (Koronios, Psiloutsikou, Kriemadis, Zervoulakos, \& Leivaditi, 2016). In this regard, it seems necessary to deepen the knowledge of the role of sponsorship on how spectators identify themself with their favorite team. Fan identification has been considered a determinant on how sponsors can act, however, the effect of perceived congruence between sponsor and sponsored has not been adequately considered for measurement. 
The current growth of sponsorship has expressed its ability to obtain crucial results in marketing. For exemple in 2000, companies invested nearly US $\$ 25$ billion in sponsorship (Tripodi, Hirons, Bednall, \& Sutherland, 2003), hence, IEG (2017) foresaw an increase of US $\$ 57$ billion in the year of 2018, representing a 130\% growth. Sport captures more than two-thirds of corporate sponsorship investments (IEG, 2017), being football the most funded in numbers and capitals (Buhler, Heffernan, \& Hewson, 2007).

Football secured sponsorship contracts amounting to US $\$ 4.5$ billion, and sponsor profit in the five biggest leagues (i.e. England, Spain, Germany, Italy, and France) accounted for $€ 3.997$ million in the 2016-2017 season (Deloitte, 2018). According to the Economist (2008), sponsoring the UEFA Champions League can cost up to $€ 150$ million. For example, Nissan closed a $€ 53$ million sponsorship contract with UEFA, representing one of the top 8 sponsors (Popovic, 2018). Looking at football clubs, Adidas signed the biggest contract ever of $€ 1100$ billion for ten years with Real Madrid FC (Carpio, 2018). In 2015, Emirates Airlines signed a $€ 8$ million constract with Sport Lisboa e Benfica for sponsoring their professional football jerseys.

The main purpose of the present research is to determine how fan identification with sports team influences perceived congruence between the sponsor and the team and intentions towards sponsorship products. Second, we intend to determine the influence of perceived congruence on purchase intention towards sponsorship products and identify the mediation effect of perceived congruence between fan identification and intentions towards buying.

Results will give sponsors how to guide their marketing strategies. Mediation is seens as a research prioritiy on sponsorship assessment (Cornwell, Weeks, \& Roy, 2005) and ' ... studies on intentions to buy, integrate, maybe, the most useful indicators of the sponsorship effect of future sales' (Crompton, 2004, p. 278). At the management level, this research has two focus groups: professional football team manager and sponsor managers. In order to maximize sponsorship value, these professionals need to adequalty understand the determinant factors of fans intention towards buying sponsor products.

Are fans more likely to purchase products from the sponsoring company if they identify themselves more with their favorite team? To maintain cognitive consistency, does perceived congruence between sponsor and sponsored team impact intentions towards buying sponsor products? Last, does perceived congruence play a mediation role, able to increase the effects of fan identification on intentions on purchasing sponsors' products?

Research analyzing the efficacy of sponsorship on leisure-time activities, specifically in football leagues, considering previous-mentioned theoretical constructs are scarce. In fact, only four studies (Han, Choi, Kim, Davis, \& Lee, 2013; Koronios et al., 2016; Lings \& Owen, 2007; Wang, Cheng, Purwanto, \& Erimurti, 2011; Zaharia, Biscaia, Gray, \& Stotlar, 2016) have taken into account the effect of fan identification with several sponsorship related outcomes.

\section{Theoretical background}

One of the main sponsorship research objectives consist on analyzing the effects of sponsorship activity on consumers, called 'consumer-focused view of sponsorship' (Ruth \& Simonin, 2003, p. 20), and referred to as 'measurement of sponsorship effects' (Cornwell 


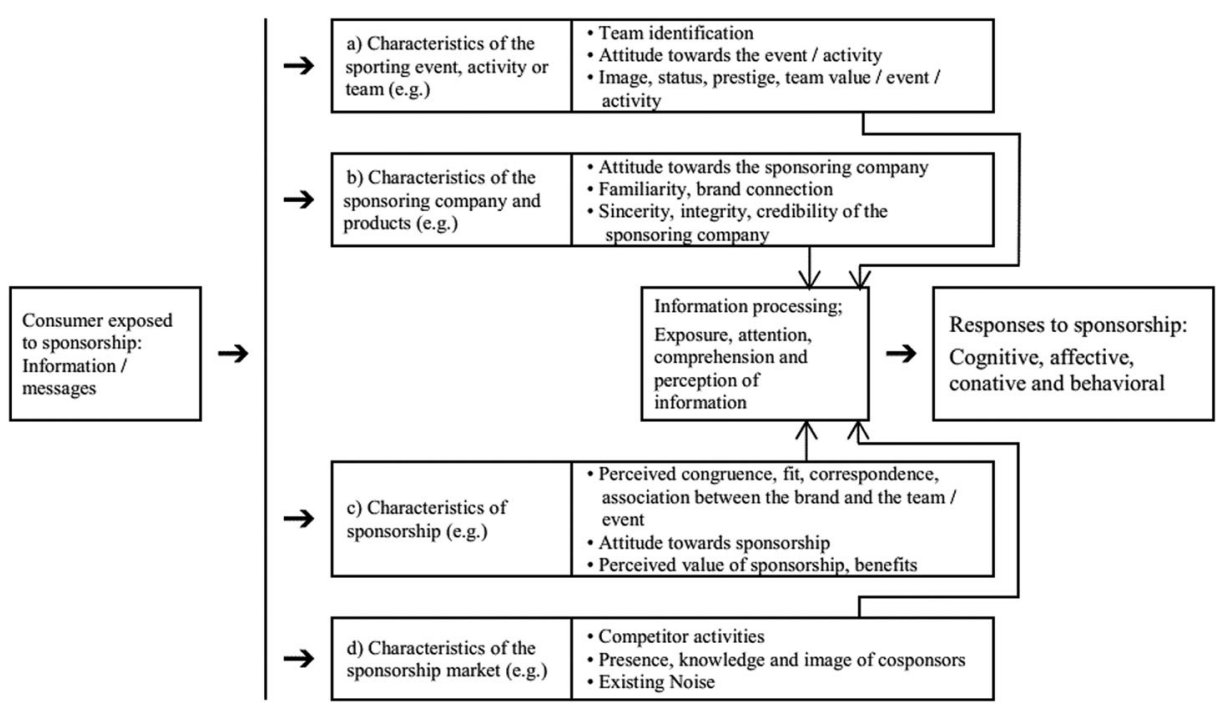

Figure 1. Systematization of the effects of sponsorship determinants on consumers responses.

and Maignan (1998, p. 2). It is a perspective driven on the effects of consumer behavior as a fan of sports team, and the factors that determine these effects. The factors that have been evidenced with ability to influence and determine the responses of spectators are based on characteristics, such as: (a) the sporting event / activity / sport team; (b) the sponsoring company / products; (c) the relationship between sponsor and sponsored team, and; (d) the sponsorship market. Figure 1 summarizes a global synthesis of the factors determining the sponsorship effects.

Available literatures allows us to sustain a set of assumptions in the factors associated with the characteristics of the sport event or team. Team identification has shown to exert effects on sponsorship responses, since it presents the business basis. In fact, as stated by Meenaghan (2013), the unique competence of sponsorship is its capacity to engage with consumers with their lifestyle setting, while facilitating bonding experiences through involvement with their passions.

Regarding sponsorship characteristics, perceived congruence between the sponsor and the sponsored team has equally shown effects on sponsorship related outcomes. Specifically, the connection between these two parties (i.e. sponsored team and sponsoring company) is intend to leverage secondary brand associations (Keller, 1993) and leads consumers to believe that the brand company shares positive associations with that sponsored entity. The harmony and perceived adequacy of these associations reflect the essence of the congruence concept.

\section{Fan identification with sport team}

The association between fan and sport is truly an omnipresent fenomenon in Western culture.

For example, Germany holds the record for the highest average audience of 43,449 spectators per game in the 2018-2019 season: 13,295,405 Germans watched Bundesliga 
matches (16.5\% of Germany's population); in England, 14,503,954 spectators (23.6\% of the population of England [Worldfootball, 2019]); and more surprisingly, the Portuguese First League had a total of $3,577,720$ spectators (33.8\% of the population of Portugal [LPFP, 2019]).

The behavior of watching football games stem some kind of importance individuals credit these sports events.

Recently, the concept of fan identification with sport team has been recently given full consideration, aiming to understand its influence on several outcomes, including how it can impact sponsorship. In fact, the study conducted by Cialdini et al. (1976) has opened a path for other studies (Heere \& James, 2007; Lings \& Owen, 2007; Smith, Graetz, \& Westerbeek, 2008; Wann \& Branscombe, 1993; Wann \& Pierce, 2003) analyzing the association between fans/expectators and sports team.

In a conceptual formulation accepted by the scientific community, fan identification with sport team is defined by '... the degree in which individuals perceive themselfes as sport fans, being engage with the team, are concerned with team's performance, and see the team as a self-representation.' (Branscombe \& Wann, 1992, p. 1017).

Regarding the concept of fans identification, Social Identity Theory (SIT) (Tajfel \& Turner, 1979) has been used widely to explain its effect, standing out two main principles: (i) individuals seek to integrate and/or maintain themselves in social groups based on the need to define a certain identity. Being member of a certain group can have a positive contribution to his social identity; and (ii) in the sport team context, comparions between groups and other relevant groups constitute a fundamental part. Individuals manifest a tendency to favorably evaluate their sports team (his social group), especially when compared with other rival teams (other relevant groups).

Literature has shown that fan identification with sport team is an important predictor of fans reactions concerning the sponsorship of sport team. Fans who feel themselves heavenly identified with their sport team are more prone to consider buying products from sponsors compared to those with lover levels of identification (Alexandris \& Tsiotsou, 2012; Deitz, Myers, \& Stafford, 2012; Lings \& Owen, 2007; Madrigal, 2001; Smith et al., 2008; Tsiotsou \& Alexandris, 2009).

Following this notion o fan identification, according to Evaluative Consistency (EC) (Madrigal, 2001), it is expected that fans with higher levels of identification with sport team perceive an empathy between the sponsoring company and their favorite team. Thus, the leaning of favoring in the highly identified fans can be extended to companies that support the favorite team through sponsorship. As stated by Congruence Theory (CT) (Osgood \& Tannenbaum, 1955), it is likely that fans with higher levels of identification desire a harmony in their beliefs and see sponsoring companies as important part with their favorite sport team. On the other hand, it would be unbalanced and incongruent to recognize the team as a positively valued element connected to a negatively one, such as the sponsor. Nevertheless, results show inconsistencies: Deitz et al. (2012) show that fan identification with the sporting event did not had a positive effect on perceived congruence, while others (Gwinner \& Bennett, 2008; Lacey \& Close, 2013) confirmed that high levels of fan identification resulted in increased perceived congruence.

In order to maintain cognitive consistency it is expected the tendency for fans with higher levels of identification to perceive an affinity link with the sponsor company of the favorite team. 
Hence:

H1: Fan identification has a positive significant and direct effect on perceived congruence between sponsor and sponsored team.

\section{Purchase intentions}

Intentions to buy sponsor products establishes as consumers response which has been considered the ultimate indicator of the sponsorship effectiveness (Madrigal, 2001). So, sponsors supporting fans' favorite sport team could be perceived as a paternalistic member of the group. Results show that individuals with higer levels of identification are more likely to present higher purchase intentions towards sponsor products compared to those with lower levels (Dees, Bennett, \& Villegas, 2008; Deitz et al., 2012; Gwinner \& Swanson, 2003; Kim, Smith, \& James, 2010; Koronios et al., 2016; Lings \& Owen, 2007; Madrigal, 2000, 2001; Zhang, Won, \& Pastore, 2005). However regarding the football context, few studies have considered these sponsorship related outcomes (Koronios et al., 2016; Lings \& Owen, 2007). Sponsor companies seem to reinforce the individual's belonging to the group since a key aspect of fan identification is that individuals are motivated to establish and maintain ties within the group through their behaviors (Fisher \& Wakefield, 1998). Hence:

$\mathrm{H} 2$ : Fan identification with their favorite team has a positive and significant effect on intentions towards buying sponsor products.

\section{Perceived congruence between sponsor and sponsored team}

Sponsorship is considered ' ... an investment, in cash or other specie, an activity, a person or sponsored event, in exchange for access by the investor (sponsor) to a commercially exploitable potential associated with such activity, person or event.' (Meenaghan, 1991, p. 36). The term congruence has been used widely to reference the idea of kinship, similarity, affinity or harmony between the sponsor and the sponsored (Cornwell et al., 2005; Deitz et al., 2012; Fleck \& Quester, 2007; Meenaghan, 2001; Roy, 2010). It can be defined as the global perception of a ' ... logical connection between both parties of the relationship.' (Meenaghan, 2001, p. 105). Therefore, the more common points there are between the sponsor and the sponsored team, the greater the tendency consumers will develop to consider favorably the sponsor (Cornwell et al., 2005).

Although most research shows that perceived congruence has positive effects on intentions towards buying products (Dees, Bennett, \& Ferreira, 2010; Dos Santos, Vveinhardt, Calabuig, \& Montoro-Ríos, 2016; Gwinner \& Bennett, 2008; Han et al., 2013; Olson \& Thjømøe, 2011; Roy, 2010; Speed \& Thompson, 2000; Wang, 2017; Zaharia et al., 2016), including rival party (Angell, Gorton, Bottomley, \& White, 2016) and misleadingly sponsoring brands (Devlin \& Billings, 2018), there are evidence reporting the oposite (Dos Santos \& Calabuig, 2018; Mazodier \& Merunka, 2012; Prendergast, Poon, \& West, 2010; Wang et al., 2011).

However, facing these contradictory results, the dominant ones were considered, in which it is reasonable to believe that fans who perceive higher levels of perceived 
congruence between the sponsor and the sports team are more intended to buy products from sponsoring companies. In this regard:

H3: Perceived congruence between sponsor and sponsored team has a positive and significant direct effect on intentions towards buying sponsor products.

Considering previous literature and formulated hipotesis, it is expectable perceived congruence to play a mediation role between fans indentification and intentions. Hence:

H4: Perceived congruence mediates positively and significantly fans identification with their favorite team and intentions towards purchasing sponsor products.

\section{Theorical model current research}

The designed conceptual model for this research integrates the construct of purchase intention as a response to fans positive perception towards sponsoring brands. As predictors of supporter responses, it was settled to adopt two constructs: (i) fan identification with sport team, and (ii) perceived congruence between the sponsor and the sponsored. The model was specified to allow the evaluation of the relative and integrated importance of constructs, based on the following proposition of hypotheses: $(\mathrm{H} 1)$ Fan identification with the sports team has a direct positive effect on perceived congruence between the sponsor and the sponsored (i.e. sports team); (H2) Fan identification with sport team has a direct and positive effect on intentions towards buying sponsor products, $(\mathrm{H} 3)$ Perceived congruence between the sponsor and the sponsored sports team has a direct and positive effect on intention towards buying sponsor products from sponsorship brands, and; (H4) Perceived congruence will mediate the relation between fan identification and purchase intention on sponsor products. See Figure 1 for a better understanding of the proposed research.

\section{Methods}

\section{Participants and procedure}

In total, 1399 male football fans, aged between 16 and 75 years $(M=34.01$; $S D=7.95)$, were considered for analysis. Regarding participants characterstics: $87 \%$ were married; $83.6 \%$ were employed; and, $57.6 \%$ had a college degree. This sample is part of a larger one $(N=1872)$, however, some participants presented missing data and observations considered outliers.

Researchers contacted one of the three most supported football team in Portugal, due to the high number of registed fans. According to UEFA, this club has approximatly 235 thousand active club members (Sportmultimedia, 2014). The main sponsor of this football team is one of the most famous beer brand in Portugal. Portugal is one of the countries with the largest beer consumption per capita in Europe with 51 liters; value above Spain 48 liters, France 33 liters and Italy 32 liters (The Brewers of Europe, 2018). The brand is displayed on the players jerseys and in several places around the footballs' sport facilities.

The multi-section survey was given to potential participants through an online platform sent by the football team to a randomly set of members. Confidentiality was granted to all potencial participants and informed consent was signed prior to filling 
out questionnaires. Participants were selected for an alysis based on several inclusion criteria: (a) Portuguese residence; (b) male and female members; and, (c) age range between 16 and 75 years.

\section{Measures}

For translating and adapting the instruments from original language to Portuguese, we followed the methodological prodecures recommended by several authors (Theodorakis, Wann, Carvalho, \& Sarmento, 2010; Vallerand, 1989). Participants respondend to several questionnaires related to all theoretical concepts under analysis (see Table 1).

\section{Statistical analysis}

Descriptive statistics (mean, standard deviation), factor loadings, and Composite Reliability (CR) were asseded for all theoretical constructs. Afterwards, we followed Kline's (2011) two-step model analysis using the Maximum Likelihood (ML) method in IBM SPSS AMOS v20.0. First, a Confirmatory Factor Analysis (CFA) was perfomed, testing the psychometric propreties of the model. In addition, convergent and discriminant validity was checked to acknowledge that the items converge into their predefined factor, and that the factors under analysis are sufficiently disctint between them, respectively. Average Mean Extracted (AVE) was considered to assess convergent validity, accepting values above .50 (Hair, Black, Babin, \& Anderson, 2014). To achieve discriminant validity, squared correlation among concepts had to be below AVE, as recommended by several authors (Hair et al., 2014; Kline, 2011).

After accepting fit adjustment of the measurement model, a Strucutral Equation Model (SEM; Arbuckle, 2007) was conducted, respecting a set of assumptions: (1) sample size ensured sufficient variability to estimate the model parameters, as suggested by Hair et al. (2014); and, (2) skweness and kurtosis should be contained within cutoffs, as recommended by Kline (2011). The score for multivariate was above cutoffs $(>5)$, rejecting the assumptions for normality. However, in large sample sizes, the violation of normality is not problematic, in such a way that Amemiya and Anderson (1990) showed the existence of asymptotic robustness of the normality assumption. Therefore, we used a Bollen-Stine bootstrap of 2000 samples as recommended by Nevitt and Hancock (2001); (3) theoretical concepts were measured by three or more items; (4) Variance Inflation Factor (VIF) analysis exhibited scores below 5, fact that represents the absence of multicollinearity, as advised by O'Brien (2007), and; (5) 152 participants were removed, since they presented squared Mahalanobis Distance $\left(\mathrm{DM}^{2}\right)$ above acceptable.

Table 1. Theoretical concepts and measurement instruments.

\begin{tabular}{|c|c|}
\hline Theoretical concepts & Measurement instruments \\
\hline Fan identification & Adapted from: (Dimmock \& Grove, 2006) \\
\hline $\begin{array}{l}\text { Perceived congruence between sponsor } \\
\text { and sponsored }\end{array}$ & Adapted from: (Gwinner \& Bennett, 2008; Speed \& Thompson, 2000) \\
\hline $\begin{array}{l}\text { Purchase intention to the sponsor's } \\
\text { products }\end{array}$ & $\begin{array}{l}\text { Adapted from: (Biscaia et al., 2013; Kim et al., 2010; Madrigal, 2001; } \\
\text { Tsiotsou \& Alexandris, 2009) }\end{array}$ \\
\hline
\end{tabular}


Model fit of CFA and SEM was measured according to the traditional goodness-of-fit indexes, namely: Comparative Fit Index (CFI), Tucker-Lewis Index (TLI), Standard Root Mean Residual (SRMR), Root Mean Square Error of Approximation (RMSEA), and its Confidence Interval of $90 \%$ (CI90\%). For these indexes, recommendations from several authors (Hair et al., 2014; Kline, 2011) were followed: CFI and TLI $\geq .90$, SRMR and RMSEA $\leq .80$.

\section{Results}

\section{Confirmatory factor analysis}

The measurement model displayed acceptable fit to de data: $\left[X^{2}=431.238(237) ; X^{2} / d f=\right.$ 1.82; $\mathrm{B}-\mathrm{S} p<.001, \mathrm{TLI}=.91, \mathrm{CFI}=.92, \mathrm{SRMR}=.05, \mathrm{RMSEA}=.05(\mathrm{Cl} 190 \%=.05, .06)]$. Standardized factor weights were above .50 with statistical significance, except for item IAP3 and IAO2, as expressed in Table 2. Moreover, all constructs demonstrate no problems of convergent and discriminant validity, except between ICA and IAP (see Table 3). Therefore, these two concepts were encompassed into one factor (i.e. ICAAP).

\section{Structural Equation Modeling}

As in CFA, the structural model presented acceptable fit to the data: $\left[X^{2}=759.19(101) ; X^{2} /\right.$ $d f=7.51 ; \mathrm{B}-p<.001, \mathrm{TLI}=.93, \mathrm{CFI}=.94, \mathrm{SRMR}=.05, \mathrm{RMSEA}=.07(90 \% \mathrm{Cl}=.06, .07)]$. Regarding direct effects, fan identification with sport team showed a positive and

Table 2. Descriptive statistics, standardized factor loadings and composite reliability coefficients.

\begin{tabular}{|c|c|c|c|c|}
\hline Constructs/itens & Mean & $S D$ & $\beta$ & CR \\
\hline Fan identification & 6.41 & .86 & & \\
\hline ICAAP & 5.75 & .93 & $.918^{* *}$ & .786 \\
\hline ICA1 - I think of my favorite team [team name] as part of who I am. & 6.34 & 1.26 & $.506^{* *}$ & \\
\hline ICA2 - My favorite team's [team name] successes are my successes. & 5.49 & 1.55 & $.613^{* *}$ & \\
\hline ICA3 - Attributes that define fans of my favorite team [team name] apply to me also. & 5.60 & 1.66 & $.607^{* *}$ & \\
\hline IAP1 - My favorite team [team name] has a lot to be proud of. & 6.57 & .97 & $.642^{* *}$ & \\
\hline IAP2 - I am proud to be a fan of my favorite team [team name]. & 6.58 & .95 & $.597^{* *}$ & \\
\hline IAP3 - My favorite team [team name] is worth supportin. & 6.71 & .91 & $.431^{* *}$ & \\
\hline IAO & 5.02 & .97 & $.567^{* *}$ & .777 \\
\hline IAO1 - Others have a positive view of my favorite team [team name]. & 5.56 & 1.41 & $.544^{* *}$ & \\
\hline IAO2 - Others respect my favorite team [team name]. & 5.42 & 1.60 & $.463^{* *}$ & \\
\hline $\begin{array}{l}\text { IAO3 - Most people consider my favorite team [team name] to be better than rival } \\
\text { teams. }\end{array}$ & 5.23 & 1.78 & $.612^{* *}$ & \\
\hline Perceived congruence between sponsor and sponsored & 4.01 & 1.47 & & .885 \\
\hline $\begin{array}{l}\mathrm{C} 1 \text { - There is a logical connection between the event and the sponsor [team name] } \\
\text { and [company/brand name]. }\end{array}$ & 3.99 & 1.90 & $.870^{* *}$ & \\
\hline C2 - The sponsor [company/brand name] and the team [team name] fit together well. & 4.42 & 1.81 & $.937^{* *}$ & \\
\hline $\begin{array}{l}\text { C3 - The company [company/brand name] and the event [team name] stand for } \\
\text { similar things. }\end{array}$ & 3.13 & 1.90 & $.740^{* *}$ & \\
\hline $\begin{array}{l}\text { C4 - It makes sense to me that this company [company/brand name] sponsors this } \\
\text { event [team name]. }\end{array}$ & 4.40 & 1.85 & $.870^{* *}$ & \\
\hline Purchase intention towards sponsor products & 3.87 & 2.05 & & .909 \\
\hline PI1 - I would be more likely to buy of [company/brand name] over its competitors. & 4.20 & 2.40 & $.927^{* *}$ & \\
\hline $\begin{array}{l}\mathrm{PI} 2 \text { - Whenever possible, I try to buy products made by [company/brand name] that } \\
\text { sponsor the team [team name]. }\end{array}$ & 3.84 & 2.34 & $.976^{* *}$ & \\
\hline $\begin{array}{l}\mathrm{PI} 3 \text { - I am likely to buy more products from [company/brand name] sponsoring [team } \\
\text { name]. }\end{array}$ & 3.73 & 2.40 & $.806^{* *}$ & \\
\hline
\end{tabular}

Note: $M=$ mean; $S D=$ standard deviation; $\beta=$ standardized factor loadings; ${ }^{* *} p<.001 ;$ ICAAP $=$ Cognitive/Affective and Personal Avaluative Identification; IAO - Other Evaluative Identification. 
Table 3. Matrix Correlation between constructs, Average Variance Extracted (AVE) and correlation among squared factors.

\begin{tabular}{|c|c|c|c|c|c|c|c|}
\hline & AVE & & ICA & IAP & IAO & $C$ & $\mathrm{Pl}$ \\
\hline ICA & .551 & $\begin{array}{l}\phi \\
\phi^{2}\end{array}$ & $\begin{array}{l}0.742^{* *} \\
0.551\end{array}$ & & & & \\
\hline IAP & .656 & $\begin{array}{c}\phi \\
\phi^{2}\end{array}$ & $\begin{array}{l}.860^{* *} \\
.740\end{array}$ & $\begin{array}{l}.81^{* *} \\
.656\end{array}$ & & & \\
\hline IAO & .538 & $\begin{array}{l}\phi \\
\phi^{2}\end{array}$ & $\begin{array}{l}.08^{* *} \\
.258\end{array}$ & $\begin{array}{l}.527^{* *} \\
.278\end{array}$ & $\begin{array}{l}.734^{* *} \\
.539\end{array}$ & & \\
\hline C & .659 & $\phi$ & $\begin{array}{l}.374^{* *} \\
.140\end{array}$ & $\begin{array}{l}.286^{* *} \\
.082\end{array}$ & $\begin{array}{l}.354^{* *} \\
.125\end{array}$ & $\begin{array}{l}.812^{* *} \\
.659\end{array}$ & \\
\hline $\mathrm{PI}$ & .771 & $\begin{array}{c}\phi \\
\phi^{2}\end{array}$ & $\begin{array}{l}.334^{* *} \\
.112\end{array}$ & $\begin{array}{l}.221^{* *} \\
.049\end{array}$ & $\begin{array}{l}.263^{* *} \\
.069\end{array}$ & $\begin{array}{l}.607^{* *} \\
.368\end{array}$ & $\begin{array}{l}.878^{* *} \\
.771\end{array}$ \\
\hline
\end{tabular}

Note: $\phi=$ Correlation between constructs; $\phi^{2}=$ correlation among squared factors. ${ }^{*}{ }^{*} p<.001 ;{ }^{*} p<.05 ;$ ICA $=$ Cognitive/ Affective Identification; $I A P=$ Personal Evaluative Identification; $I A O=$ Other Evaluative Identification; $C$ - Perceived congruence between sponsor and sponsored; $\mathrm{PI}=$ Purchase intention towards sponsor products.

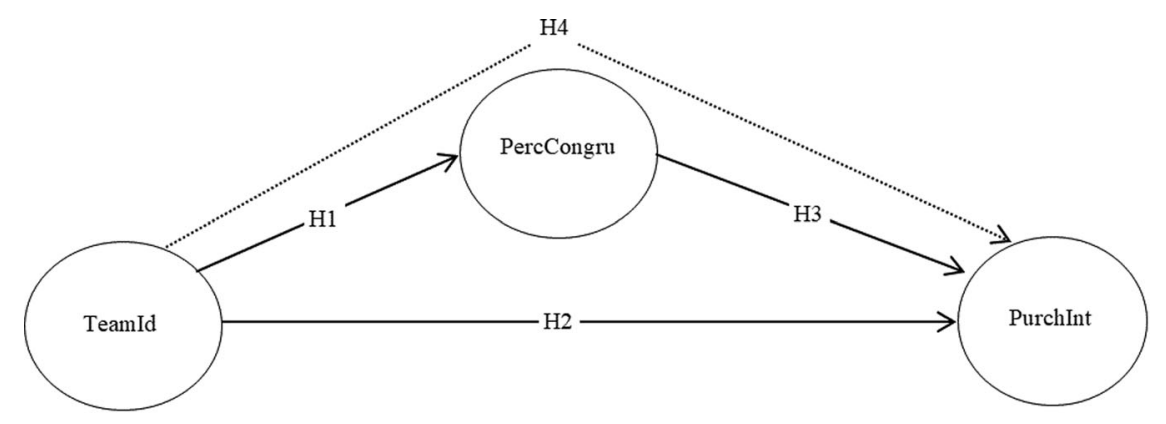

Figure 2. Conceptual model.

significant effect on perceived congruence between sponsor and sponsored, and on purchase intentions towards sponsor products. In addition, perceived congruence had a positive and significant effect on intentions towards buying sponsor products. In total, the model showed a performance that explained $45 \%$ of the variation in purchase intentions. (see Figure 2 and Table 4 for more detail). Perceived congruence between sponsor and sponsored showed to excert a mediation role, expressed between fans identification with the team and purchase intentions towards sponsor products. Consequently, the indirect effects stated $53 \%$ of explained variance, as seen in Table 4. (Figure 3).

\section{Discussion}

Current research aimed to examine the effect of fans identification with their favorite team on several outcomes related to sponsorship. This research provides results that are generalizable to the football-sponsor industry, as the present sample represent clearly what fans identification with the team can predict intentions on buying sponsors products. The large sample size lends reliability to the present findings, making it of great utility for researchers, sport managers, as well as sponsor managers.

Results showed that fans identification has a significant and positive effect on perceived congruence between sponsor and sponsored team $(\mathrm{H} 1)$. This result shows the bright side, it is very relevant as it reinforces the principle that individuals who tend to 
Table 4. Path estimates for the direct, indirect and total effects.

\begin{tabular}{|c|c|c|c|c|c|c|}
\hline Path estimate & Result & B & \multicolumn{4}{|c|}{$Z$} \\
\hline $\begin{array}{l}\mathrm{H} 1: \quad \text { Identification } \rightarrow \\
\quad \text { Congruence }\end{array}$ & Confirmed & $.18^{* *}$ & 5.527 & & & \\
\hline $\begin{array}{l}\text { H2: Identification } \rightarrow \text { Purchase } \\
\text { intention }\end{array}$ & Confirmed & $.10^{* *}$ & 4.097 & & & \\
\hline \multirow[t]{3}{*}{ H3: Perceived congruence $\rightarrow$} & Confirmed & $.65^{* *}$ & 25.827 & & & \\
\hline & Mediation role & & B & & & $\%$ Indirect \\
\hline & & & Direct & Indirect & Total & Effect \\
\hline H4: Purchase intentions & $\begin{array}{l}\text { Fan identification mediated by } \\
\text { perceived congruence }\end{array}$ & Confirmed & $.100^{* *}$ & $.113^{* *}$ & $.213^{*}$ & 53 \\
\hline
\end{tabular}

Note: ${ }^{*} p<.001 ;{ }^{*} p<.05$.

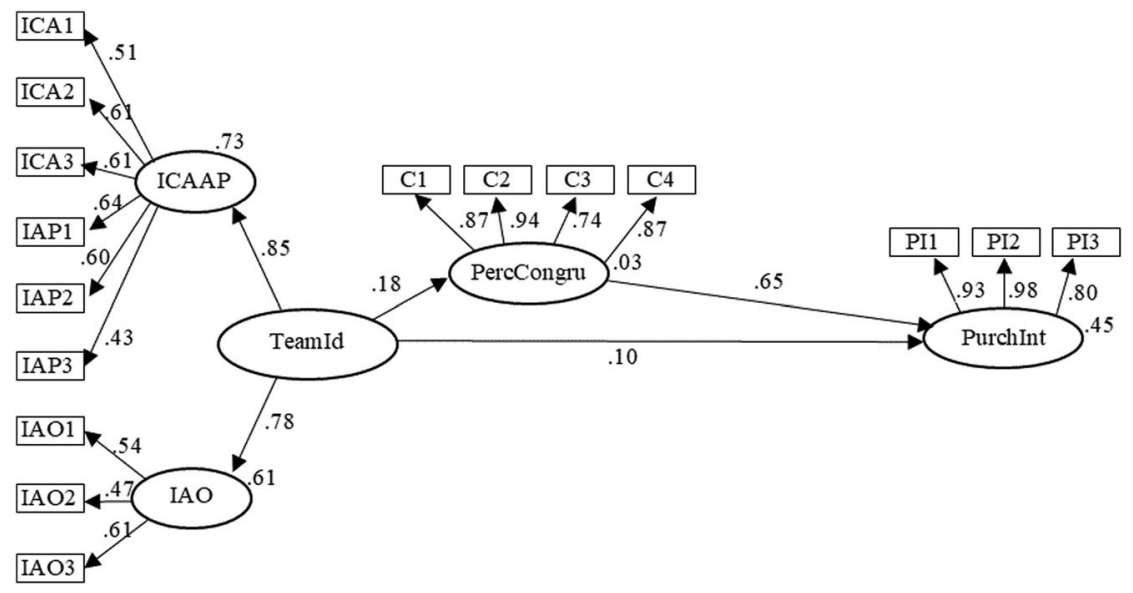

Figure 3. Standardized coefficients of the structural model.

perceive congruence with the salient aspects of their own identities, are prone to consider resemblance with institutions which embody these identitites (Tajfel \& Turner, 1979), such as sponsor brands with sport team which they support.

Although developed in different contexts of football, the results obtained support the conclusions: Gwinner and Bennett (2008): Spectators, dew action sports tour events; Lacey and Close (2013): Spectators, cycling event: the level of fan identification has a positive direct effect on perceived congruence between the sponsor and the sponsored activity.

However, Deitz et al. (2012) displayed oposite results, showing that fan identification with a college team did not predicted perceived congruence between a fictitional sponsor and the sport team. Thus, it is possible that the fictional bond created between sponsor and sponsored in their study had not a strong impact on fans, contrarily to present research, in which both parties have a long partnership history (longer than 8 years). Another reasons for these divergences between their results and current study may be rooted in the type of study and sporting activities: Deitz et al. (2012) conducted an experimental study, using university's athletic programs. On the other hand, this study was cross-sectional in its design, assessing real fans' percepetion on sponsors and sponsored football team. 
Fans' identification predicted positively and significantly intentions towards buying sponsor products $(\mathrm{H} 2)$, explaining $45 \%$ of variance. This result reinforces the bright side of the team identification construct. These results corroborate with Ashmore, Deaux, and McLaughlin-Volpe (2004), which explain current findings based on the conceptual element of the behavioral involvement that structures the definition of adopted social identity. The behavioral involvement can be translated into actions like buying merchendising, wearing allusive clothing to the sports team, waving flags, exposing team symbols or investing time and resources to organizations that safeguard and promote the identity of their favorite sports team (Heere \& James, 2007). Fans highly wrapped tend to act in a way that strengthens their ties with group members, as explained by Social Identity Theory (SIT) (Tajfel \& Turner, 1979). Therefore, it seems plausible that purchase intention can take this form of support to the companies sponsoring their favorite sports team. Several studies align with this knowledge of fan identification with sport team and its prediction on intentions towards buying sponsor products (Dees et al., 2008; Deitz et al., 2012; Gwinner \& Swanson, 2003; Kim et al., 2010; Koronios et al., 2016; Lings \& Owen, 2007; Madrigal, 2001; 2000; Zhang et al., 2005).

The direct effect of perceived congruence between sponsor and sponsored on purchase intention was positive and significant $(\mathrm{H} 3)$. Spectators perceiving a real connection between sponsor and sponsored team develop a greater tendency to acquire the sponsoring company's products. This has been enlightened by Osgood and Tannenbaum (1955), in which harmony and congruence lead to a greater compliance of consumers to recall and relate the sponsors in a favorable manner. Current results corroborate with several empirical studies, assessing current tenets (Dees et al., 2010; Dos Santos et al., 2016; Gwinner \& Bennett, 2008; Han et al., 2013; Olson \& Thjømøe, 2011; Roy, 2010; Speed \& Thompson, 2000; Wang, 2017; Zaharia et al., 2016). Nevertheless, other studies have shown opposite results (Dos Santos \& Calabuig, 2018; Mazodier \& Merunka, 2012; Prendergast et al., 2010; Wang et al., 2011). This divergence could be explained by the level of perceived congruence as a predictor of behavioral outcomes. We hypothesize that fans need to understand the degree of sponsor's commitment with sponsoring sport teams in order to create a positive (or negative) connection between both parties. In a theoretical point-of-view, the reasons for these opposite results may be rooted in the type of study and sporting activities: Dos Santos and Calabuig (2018) conducted an experimental study using encephalogram (EEG), measuring participants perception of current tenets on six sports (i.e. sailling, formula 1, tennis, triathlon, popular races and rowing). The study performed by Mazodier and Merunka (2012) was also experimental in its design, measuring spectators percpetions of the 2008 Olympic Games in Beijing. Prendergast et al. (2010) conducted likewise a experimental study, manipulating two types sponsors. Last, Wang et al. (2011) recruited baseball and soccer teams spectators, which could have impacted diverge results with current study.

When it comes to indirect effect, fan identification explained $53 \%$ of variance on intentions towards purchasing sponsor products, showing how perceived congruence plays a crucial mediation role. Perceived congruence facilitates the processing of information as a result from the association that emerges among sponsor company and the sponsored activity (Fleck \& Quester, 2007). In overall, we suggest fan identification with sport team as a powerfull predictor, not only to perceived congruence, but likewise on purchase intentions towards sponsor products directly and indirectly via congruence. 


\section{Theoretical implications}

Present results have particular theoretical implications that need to be highlighted. First, the relevant contribute as referenced by several authors (Cornwell, Humphreys, Maguire, Weeks, \& Tellegen, 2006; Dos Santos \& Calabuig, 2018), relatively to the lack of existing literature on assessing the mediation role of perceived congruence between sponsor and sponsored team. Current results showed that perceived congruence has a significant mediation effect between fans identification and intentions towards buying sponsor products, showing that it can represent an increase on sponsor product purchase, aligning with theoretical assumptions (Olson \& Thjømøe, 2011; Zaharia et al., 2016). Second, regarding to the football context, fan identification constitutes the cognitive and affective basis for optimal functioning of other variables related to sponsorship (Biscaia, Correia, Rosado, Ross, \& Maroco, 2013). Last, perceived congruence, as explained by Congruence Theory (CT) (Osgood \& Tannenbaum, 1955), is essential to study when it comes to understanding sponsorship efficacy (Fleck \& Quester, 2007).

\section{Managerial implications}

Results suggest implications for both football club managers and brand and sponsor company managers. Sports managers should develop activities to increase fans' identification level, especially to ones with lower levels, since findings indicate higher intentions towards buying sponsor products if they feel bounded with their favorite team. Recent tendencies show that certain factors, such as increased ticket cost, bad team performance, high salaries paid to players and their incorrect conduct could decrease fan identification. Therefore, managers should be attentive and control exposed information to fans/spectators. Thus, fan segmentation by level of identification seems to be a plausible alternative.

As current results show, fans with higher levels of identification with their favorite team perceive likewise higher congruence between sponsor and sponsored. Consequently, sport managers should create bounding activities as a way to promote social interaction between parties, leading to greater degree of identification. In turn, behavioral norms could reinforce the association between fan identification and intentions towards certain behaviors (e.g. cheering, assisting to games, buying merchandising).

The mediation role of perceived congruence advises sponsor managers to implement sponsorship strategies as a way to increase fans' perceived congruence between them and the team they support. These operations should be perceived by fans as empathetic and genuine, in order to lead to perceptions of greater congruence and, finally, to more favorable attitudinal responses.

Sponsor company managers should consider perceived congruence as a significant factor to consider, since it suggests and advises the implementation of sponsorship strategy with the aim of increasing the level of perceived congruence between the sports team and the sponsor company. The brand activation operations should be harmoniously and honestly implemented in order to lead to higher level congruence perception, and finally lead to more favorable attitudinal responses. 


\section{Limitations and agenda for future research}

There are some limitations that should be considered. The sport team and sponsor company used in the present research as stimulus are real brands with high consumer awareness and familiarity. According to Roy (2010), this could lead individuals ro react on the measurement scale based informational memory and less based on the stimuli presented during the application of the questionnaire. Assessing the impact of less notorious brands could lead to different results and compare them would be of interest. Second, the findings were related to a bewery company sponsor, and therefore, generalize the trend should be a circumscribed and weighted process. The assessment of other sponsors from different extents (e.g. airline, sports equipment, telecom company) could give new insight on how the degree of sponsoring can influence fans' perception of congruence. Third, a convenience sample withdrawn from a range of fans identified with their favorite sports team was used. Although sample size was significant, participants were all club members and this could influence current conclusions. Forthcoming studies ought to compare different samples with different perspectives of certain football teams, or even years of membership. In addition, in the constext of sponsorship we suggest applying this analysis to amateur football league as a way to examine 'less' competitive championships.

\section{Conclusion}

Business partnerships are increasing as a marketing strategy to communicate with consumers. As already mentioned, sponsors invested US $\$ 57.5$ billion in other companies in 2018 , being sports-related brands the most supported. In an effort to influence audience attitudes, sponsor brands have engaged actively in involving themselves with sports team hopping that fan's passion for their favorite team would spread to themselves and their products. Current results allow us to highlight three crucial assumptions:

First, perceived congruence plays an important mediation role between fans' identification and intentions towards buying sponsor products. Fans perceiving a logic and balanced connection between sponsor and sponsored team are more likely to buy sponsor products of their favorite teams.

Second, the bright side of the team identification construct. Fans' identification with their favorite team was a significant predictor on fans' responses towards sponsors. Increased levels of fans identification was linked with higher intentions towards purchasing sponsor products.

Last, fans with higher levels of identification with their favorite team manifest a higher ability to see common dimensions of sponsoring company and their favorite team. In fact, in terms of Congruence Theory, it led to a high level of perceived congruence between the sponsor and the sports team.

In sum, the sponsor commitment may be the related to the opportunity for sponsoring companies to share with the sports team the 'heart' of the consumer. Fans identification with their favorite team constitutes the emotional basis for sponsoring companies to influence beliefs, attitudes, and intentions towards a given behavior on those that make up customer base. 


\section{Disclosure statement}

No potential conflict of interest was reported by the author(s).

\section{Funding}

This work was supported by Portuguese Foundation for Science and Technology, I.P. [grant number UIDP/04748/2020].

\section{ORCID}

Alfredo Silva (iD http://orcid.org/0000-0001-7703-0513

\section{References}

Alexandris, K., \& Tsiotsou, R. H. (2012). Testing a hierarchy of effects model of sponsorship effectiveness. Journal of Sport Management, 26(5), 363-378.

Amemiya, Y., \& Anderson, T. W. (1990). Asymptotic chi-square tests for a large class of factor analysis models. The Annals of Statistics, 18(3), 1453-1463.

Angell, R. J., Gorton, M., Bottomley, P., \& White, J. (2016). Understanding fans' responses to the sponsor of a rival team. European Sport Management Quarterly, 16(2), 190-213.

Arbuckle, J. L. (2007). Amos 16.0 user's guide. Amos Development Corporation. Retrieved February 25, 2020 from http://www.amosdevelopment.com/download/Amos\%2016.0\%20User's\%20Guide.pdf

Ashmore, R. D., Deaux, K., \& McLaughlin-Volpe, T. (2004). An organizing framework for collective identity: Articulation and significance of multidimensionality. Psychological Bulletin, 130(1), 80-114.

Biscaia, R., Correia, A., Rosado, A. F., Ross, S. D., \& Maroco, J. (2013). Sport sponsorship: The relationship between team loyalty, sponsorship awareness, attitude toward the sponsor, and purchase intentions. Journal of Sport Management, 27(4), 288-302.

Branscombe, N. R., \& Wann, D. L. (1992). Role of identification with a group arousal, categorization processes, and self-esteem in sports spectator aggression. Human Relations, 45(10), 1013-1033.

The Brewers of Europe. (2018). Country profiles. Retrieved June 9, 2019, from https:// brewersofeurope.org/site/countries/figures.php?doc_id=665

Buhler, A. W., Heffernan, T. W., \& Hewson, P. J. (2007). The soccer club-sponsor relationship: Identifying the critical variables for success. International Journal of Sports Marketing \& Sponsorship, 8(4), 291-309.

Carpio, C. (2018). Real Madrid and Adidas have 1,100 million euro sponsorship deal agreed. Marca. Retrieved November 5, 2018, from https://www.marca.com/en/football/real-madrid/2018/11/ 05/5bdf668fca474187598b4572.html

Cialdini, R., Borden, R., Thorne, A., Walker, M., Freeman, S., \& Sloan, L. (1976). Basking in reflected glory: Three (football) field studies. Journal of Personality and Social Psychology, 34(3), 366-375.

Cornwell, T. B., Humphreys, M. S., Maguire, A. M., Weeks, C. S., \& Tellegen, C. L. (2006). Sponsorship-linked marketing: The role of articulation in memory. Journal of Consumer Research, 33(3), 312-321.

Cornwell, T. B., \& Maignan, I. (1998). An international review of sponsorship research. Journal of Advertising, 27(1), 1-21.

Cornwell, T. B., Weeks, C. S., \& Roy, D. P. (2005). Sponsorship-linked marketing: Opening the black box. Journal of Advertising, 34(2), 21-42.

Crompton, J. L. (2004). Conceptualization and alternate operationalizations of the measurement of sponsorship effectiveness in sport. Leisure Studies, 23(3), 267-281.

Dees, W., Bennett, G., \& Ferreira, M. (2010). Personality Fit in NASCAR: An evaluation of driversponsor congruence and its impact on sponsorship effectiveness outcomes. Sport Marketing Quarterly, 19(1), 25-35. 
Dees, W., Bennett, G., \& Villegas, J. (2008). Measuring the effectiveness of sponsorship of an Elite Intercollegiate Football Program. Sport Marketing Quarterly, 17(2), 79-89.

Deitz, G. D., Myers, S. W., \& Stafford, M. R. (2012). Understanding consumer response to sponsorship information: A resource-matching approach. Psychology and Marketing, 29(4), 226-239.

Deloitte. (2018). Annual review of football finance 2018. Deloitte. Retrieved February 25, 2020 from https://www2.deloitte.com/uk/en/pages/sports-business-group/articles/annual-review-offootball-finance.html

Devlin, M., \& Billings, A. C. (2018). Examining confirmation biases: Implications of sponsor congruency. International Journal of Sports Marketing and Sponsorship, 19(1), 58-73.

Dimmock, J. A., \& Grove, J. R. (2006). Identification with sport teams as a function of the searchfor certainty. Journal of Sports Sciences, 24(11), 1203-1211.

Dos Santos, M. A., \& Calabuig, M. F. (2018). Assessing the effectiveness of sponsorship messaging: Measuring the impact of congruence through electroencephalogram. International Journal of Sports Marketing and Sponsorship, 19(1), 25-40.

Dos Santos, M. A., Vveinhardt, J., Calabuig, M. F., \& Montoro-Ríos, F. (2016). Involvement and image transfer in sports sponsorship. Engineering Economics, 27(1), 78-89.

Economist. (2008). Sponsorship form: The value of sport to other kinds of business. Economist. Retrieved February 25, 2020, from http://www.economist.com/node/11825607

Fisher, R. J., \& Wakefield, K. (1998). Factors leading to group identification: A field study of winners and losers. Psychology and Marketing, 15(1), 23-40.

Fleck, N. D., \& Quester, P. (2007). Birds of a feather flock together ... definition, role and measure of congruence: An application to sponsorship. Psychology and Marketing, 24(11), 975-1000.

Gwinner, K., \& Bennett, G. (2008). The impact of brand cohesiveness and sport identification on brand fit in a sponsorship context. Journal of Sport Management, 22(4), 410-426.

Gwinner, K. P., \& Swanson, S. R. (2003). A model of fan identification: Antecedents and sponsorship outcomes. Journal of Services Marketing, 17(3), 275-294.

Hair, J. F., Black, W. C., Babin, B. J., \& Anderson, R. E. (2014). Multivariate data analysis: Pearson new international edition. Essex: Pearson Education Limited.

Han, S., Choi, J., Kim, H., Davis, J. A., \& Lee, K. Y. (2013). The effectiveness of image congruence and the moderating effects of sponsor motive and cheering event fit in sponsorship. International Journal of Advertising, 32(2), 301-317.

Heere, B., \& James, J. D. (2007). Stepping outside the lines: Developing a multi-dimensional Team Identity Scale based on social identity theory. Sport Management Review, 10(1), 65-91.

IEG. (2017). What Sponsors want \& where dollars will go in 2018. IEG Sponsorship Report. International Event Group. Retrieved February 25, 2020, from http://www.sponsorship.com/IEG/files/f3/ f3cfac41-2983-49be-8df6-3546345e27de.pdf

Keller, K. L. (1993). Conceptualizing, measuring, and managing customer-based brand equity. Journal of Marketing, 57(1), 1-22.

Kim, Y., Smith, R., \& James, J. D. (2010). The role of gratitude in sponsorship: The case of participant sports. International Journal of Sports Marketing and Sponsorship, 12(1), 48-70.

Kline, R. B. (2011). Principles and practice of structural equation modeling (3rd ed.). New York: Guilford Press.

Koronios, K., Psiloutsikou, M., Kriemadis, A., Zervoulakos, P., \& Leivaditi, E. (2016). Sport sponsorship: The impact of sponsor image on purchase intention of fans. Journal of Promotion Management, 22 (2), 238-250.

Lacey, R., \& Close, A. G. (2013). How fit connects service brand sponsors with consumers' passions for sponsored events. International Journal of Sports Marketing and Sponsorship, 14(3), 57-73.

Lings, I. N., \& Owen, K. M. (2007). Buying a sponsor's brand: The role of affective commitment to the sponsored team. Journal of Marketing Management, 23(5-6), 483-496.

LPFP. (2019). Estatísticas Liga Nos. Liga Portuguesa de Futebol Profissional. Retrieved February 25, 2020 http://ligaportugal.pt/pt/liga/estatisticas/espectadores/clube/20182019/liganos

Madrigal, R. (2000). The influence of social alliances with sports teams on intentions to purchase corporate sponsors' products. Journal of Advertising, 29(4), 13-24. 
Madrigal, R. (2001). Social identity effects in a belief-attitude-intentions hierarchy: Implications for corporate sponsorship. Psychology and Marketing, 18(2), 145-165.

Mazodier, M., \& Merunka, D. (2012). Achieving brand loyalty through sponsorship: The role of fit and self-congruity. Journal of the Academy of Marketing Science, 40(6), 807-820.

Meenaghan, T. (1991). The role of sponsorship in the marketing communications mix. International Journal of Advertising, 10(1), 35-47.

Meenaghan, T. (2001). Understanding sponsorship effects. Psychology and Marketing, 18(2), 95-122.

Meenaghan, T. (2013). Measuring sponsorship performance: Challenge and direction. Psychology \& Marketing, 30(5), 385-393.

Nevitt, J., \& Hancock, G. R. (2001). Performance of bootstrapping approaches to model test statistics and parameter standard error estimation in structural equation modeling. Structural Equation Modeling, 8(3), 353-377.

O'Brien, R. M. (2007). A caution regarding rules of thumb for variance inflation factors. Quality \& Quantity, 41(5), 673-690.

Olson, E. L., \& Thjømøe, H. M. (2011). Explaining and articulating the fit construct in sponsorship. Journal of Advertising, 40(1), 57-70.

Osgood, C. E., \& Tannenbaum, P. H. (1955). The principle of congruity in the prediction of attitude change. Psychological Review, 62(1), 42-55.

Popovic, N. (2018). The big eight: Sponsors behind the most popular football competition. Over Time Sport. Retrieved February 15, 2019, from. http://promoovertime.com/big-eight-sponsors-behindpopular-football-competition/

Prendergast, G. P., Poon, D., \& West, D. C. (2010). Match game. Journal of Advertising Research, 50(2), 214-226.

Roy, D. P. (2010). The impact of congruence in cause marketing campaigns for service firms. Journal of Services Marketing, 24(3), 255-263.

Ruth, J. A., \& Simonin, B. L. (2003). Brought to you by brand A and brand B, Investigating multiple sponsors' influence on consumers' attitudes toward sponsored events. Journal of Marketing, 32 (3), 19-30.

Smith, A., Graetz, B., \& Westerbeek, H. (2008). Sport sponsorship, team support and purchase intentions. Journal of Marketing Communications, 14(5), 387-404.

Speed, R., \& Thompson, P. (2000). Determinants of sports sponsorship response. Journal of the Academy of Marketing Science, 28(2), 226-238.

Sportmultimedia. (2014). Benfica reforça posição como maior clube do Mundo em número de sócios. Sapo. Retrieved March 5, 2020, from http://desporto.sapo.pt/futebol/primeira_liga/artigo/2014/ 02/15/benfica_refor_a_posi_o_como_mai.html

Tajfel, H., \& Turner, J. C. (1979). An integrative theory intergroupc conflict. In M. G. Austin \& S. Worehel (Eds.), The social psychology of intergroup relation (pp. 33-47). Monterey, CA: Brooks/ Cole.

Theodorakis, N. D., Wann, D. L., Carvalho, M., \& Sarmento, P. (2010). Translation and initial validation of the Portuguese version of the Sport Spectator Identification Scale. North American Journal of Psychology, 12(1), 67-80.

Tripodi, J. A., Hirons, M., Bednall, D., \& Sutherland, M. (2003). Cognitive evaluation: Prompts used to measure sponsorship awareness. International Journal of Market Research, 45(4), 435-456.

Tsiotsou, R., \& Alexandris, K. (2009). Delineating the outcomes of sponsorship: Sponsor image, word of mouth, and purchase intentions. International Journal of Retail \& Distribution Management, 37 (4), 358-369.

Vallerand, R. J. (1989). Vers une mèthodologie de validation trans-culturelle de questionnaires psychologiques: Implications pour la recherché en langue française. Psychologie Canadienne, 30(4), 662-680.

Wang, M. C. H. (2017). Investigating the different congruence effects on sports sponsor brand equity. International Journal of Sports Marketing and Sponsorship, 18(2), 196-211.

Wang, M. C. H., Cheng, J. M. S., Purwanto, B. A., \& Erimurti, K. (2011). The determinants of the sports team sponsor's brand equity. International Journal of Market Research, 53(6), 811-829. 
Wann, D. L., \& Branscombe, N. R. (1993). Sports fans: Measuring degree of identification with the team. International Journal of Sport Psychology, 24(1), 1-17.

Wann, D. L., \& Pierce, S. (2003). Measuring sport team identification and commitment: An empirical comparison of the Sport Spectator Identification Scale and the psychological commitment to Team Scale. North Americam Journal of Psychology, 5(3), 365-372.

Worldfootball. (2019). Germany. Bundesliga 2017/2018. Attendance. Home matches. Retrieved 2020, June 1, from https://www.worldfootball.net/attendance/bundesliga-2018-2019/1/

Zaharia, N., Biscaia, R., Gray, D., \& Stotlar, D. K. (2016). No more "good" intentions: Purchase behaviors in sponsorship. Journal of Sport Management, 30(2), 162-175.

Zhang, Z., Won, D., \& Pastore, D. L. (2005). The effects of attitudes toward commercialization on college students' purchasing intentions of sponsors' products. Sport Marketing Quarterly, 14(3), 177-187. 